Saša Redžić

UDK 904:739.2"652"(497.11)

Archaeological Institute, Belgrade

$902.2(497.11)$

sasa.redzic@gmail.com

Original research article

Mladen Jovičić

Archaeological Institute, Belgrade

Received: June 24, 2010

Accepted: August 13, 2010

\title{
UNPUBLISHED FINDS OF ROMAN FIBULAS FROM THE TERRITORY OF VIMINACIUM
}

\begin{abstract}
This paper deals with previusly unpublished finds of Roman fibulas lately discovered at Viminacium. The sites on which the finds were discovered include Kod bresta, Pirivoj, Pećine, Više grobalja, Na kamenju, Humka, Kastrum, Terme, Kod koraba, Stig, Rit and Nad klepečkim. The fibulas from the sites Kod bresta, Pirivoj, Pećine, Višse grobalja and Kod koraba represent grave finds, while the rest of them represent finds from settlement areas.
\end{abstract}

Key words: Pest, fibulas, Viminacium, graves, settlement area.

The goal of this paper are the finds of Roman fibulas not previously published, which were discovered during the archaeological excavations of Viminacium. The sites they were found at include: Kod bresta, Pirivoj, Pećine, Više grobalja, Na kamenju, Humka, Kastrum, Terme, Kod koraba, Stig, Rit and Nad klepečkom. Most of the finds come from Roman cemeteries, but also within different parts of the settlement.

Most of the fibulas from our collection was made of copper alloy. ${ }^{1}$ On some of these examples, spring and needles were made of iron, which should be understood as an attempt to strenght-

1 The example 18 was made of brass. en these constructive parts, most vulnerable due to their function. Luxurious examples made of bronze include the numbers 19 and 20, decorated with enamel. The examples numbers 4, 5 and 24 were made of iron, while the numbers 21 and 22 were made of silver.

The examples with a hinge, similar to the Aucissa fibulas, are numerous at the territory of Viminacium, as well as on the whole territory of the Upper Moesia, but they are not very frequent at the territories of the Lower Moesia and Dacia (Redžić 2007: 15). According to the finds from Drobeta, A. Jovanović expresses the opinion that a workshop for their production operated in this

* The article results from the project: Viminacium, Roman city and military legion camp - research of material and non material of inhabitants by using the modern technologies of remote detection, geophysics, GIS, digitalisation and $3 D$ visualisation (no 47018), funded by Ministry of Education and Science of the Republic of Serbia. 
town (Jovanović 1978: 54). Apart from the five examples (T. I/1-5), during the earlier Viminacium excavations, fifty examples of this type were discovered, all dated into 2 nd and the first half of $3^{\text {rd }}$ century.

Four examples of strongly profiled fibulas (T. I/6-9) were discovered. Two examples possess a support, while on the other two it is missing. An example of this kind was determined into type 13 (variants B and D) by S. Petković (Petković 2010: 77). The origin of the fibulas with the support is from Noricum and Pannonia and on these territories exactly the first examples developed during 1st century. Accordng to semi-fabricates discovered in Siscia, it can be concluded that this town was one of the centres for their production and distribution. Anothe fact is that even 440 examples of these fibulas were discovered within the area of modern Sisak (Koščević 1975: 55-56). Apart from Siscia, production centres of these fibulas were also found in the dacian towns of Porolissum, Napoca and Micia (Cociş 2004: 35-36).

Strongly profiled fibulas with a support are dated into $1^{\text {st }}$ and the first half of $2^{\text {nd }}$ century. Most of the examples without a support was discovered in Danubian provinces and they can be dated into $2^{\text {nd }}$ and $3^{\text {rd }}$ century.

Strongly profiled fibulas of the PonticDanubian type are typical for Danubian provinces, often found in Dacia, Pannonia, Upper and Lower Moesia. They were often found at the northern coast of the Black sea (where semi-fabricates were discovered as well) (Амброз 1966: 40, T. 8/1-8, 10,11 ), as in the Carpathian part of Moldova (2nd and $3^{\text {rd }}$ century) (Bichir 1967: 205, fig. 24, 1, 4, 5, $7,10)$. The greatest number of these fibulas was discovered in the Upper Moesia. Apart from the finds kept at museums in Belgrade, Smederevo, Negotin, Niš and Kragujevac (Bojović 1983: 41), apart from the here presented four examples ( $\mathrm{T}$. II/10-13), at the territory of Vimnacium another 63 examples of this type were discovered, which indicates that within the Vimnacium area there could be a workshop in which they were produced (Redžić 2007: 78). This type of fibulas is dated from the end of 1 st to the middle of $3^{\text {rd }}$ cenutry.

Knee-shaped fibulas with a support and a spring are here divided into two variants. The first one is a variant with a semi-spherical support (T. II/14-15), sometimes decorated with zig-zag shaped carvings along the edges, like the example number 14. Under the support, there is a spring, mostly made out of eight windings. The here presented examples, as well as the other 27 previously published examples from Viminacium, possess an outer winding, typical for Pannonia, Noricum, Dacia, Upper and Lower Moesia (Redžić 2007: 33). Contrary to these, the inner winding is typical for Raetia, Germania and Britania (Böhme 1972: 19-20). This specifica connected to the position of the windings can also be noticed on other types of fibulas. A somewhat less frequent variant includes fibulas with an angeled support (T. II/16). Within the Viminacium area, sixteen examples were discovered so far, inclding the here presented example. Apart from the Upper Moesia, the fibulas of this variant are often encountered in Pannonia and Dacia.

In the cities from the provinces mentioned, like Brigetio, Flavia Solva, Siscia and Napoca, semi-fabricates of moulds for production of kneeshaped fibulas with a spring opruga were discovered. The finds of such fibulas from Viminacium shall be dated into $2^{\text {nd }}$ and the first half of $3^{\text {rd }}$ century, supported with the find no. 15 from the cremation grave $\mathrm{G}_{1}-66$ together with a coin of Faustina the Elder.

The knee-shaped fibulas from Viminacium include 56 examples, including the here presented one (T. II/17). Such fibulas are typical for the eastern provincies, especially for the Upper Moesia, in which they represent the most numerous type. D. Bojović names 55 examples kept at the Belgrade City Museum (Bojović 1983: 58-61, T. XXIII-XXVII, 211-266). Apart from the Limes finds, such fibulas are also discovered in the 
inland. Their number within the province of the Upper Moesia, indicate the existence of a production centre in this area, maybe Viminacium itself. Apart from the Upper Moesia, such fibulas are also encountered in Dacia and the Lower Moesia.

The finds from Viminacium deny D. Bojović's dating of this fibula type into the period from $2^{\text {nd }}$ to $4^{\text {th }}$ century. According to grave finds, the beginning of their production was in the middle of 2 nd century but they went out of use at the beginning of the second half of 3rd century. The youngest reliably dated fibula of this type was found in the grave no. G-1006 from the site „Pećine“, dated with one coin of Emilianus and three coins of Gallienus (Redžić 2007: 78).

Five examples of the fibulas with spirally bent bow were discovered at Viminacium (including the fibula T. II/18). This type of fibulas belong to the D. Bojović's variant 17 within his division of knee-shaped fibulas with a hinge (Bojović 1983: 61, T. XXVIII, 265-267). S. Petković describes these fibulas as type 20 and dates them from the second half of 2 nd to the end of $3^{\text {rd }} / \mathrm{be}-$ ginning of $4^{\text {th }}$ century (Petković 2010: 155-158). The basic spreading areas of these fibulas are the provinces along the Danube valley. According to the earlier finds from Viminacium, the author suggests their dating from the second half of $2^{\text {nd }}$ to the second third of $3^{\text {rd }}$ century.

Along with the here presented examples (T. II/19-20), 18 plate fibulas were discovered at Viminacium, often decorated with enamel or a middle tutulus shaped bulge, like on some of the here presented examples. The oldest enamel decorated examples of Roman fibulas appear during the last third of $1^{\text {st }}$ century in Western Europe. They are most numerous in Gaul, Germany and Pannonia, slightly less in the Upper Moesia.

According to the division by S. Rieckhoff, the Viminaicum plate fibulas belong to her group $\mathrm{C}$, consisting of pieces enameled in the millefiori technique, as well as examples of different shapes decorated with inlayed semi-precious stones or a tutulus in the middle, made in the striking technique. This group is dated from the middle of 2nd to the middle of $3^{\text {rd }}$ century (Rieckhoff 1975: 64-69).

In Viminacium, 17 plate-shaped fibulas made in the striking technique were discovered, including the three here presented examples ( $\mathrm{T}$. II/21-23). It should be mantioned that the examples no. 21 and 22 were made of silver. The decoration of such fibulas was made by striking through the plate-shaped body. A. Böhme considers them remains of a Celtic artistic tradition (Böhme 1972: 44). Celtic influences are to be recognized in the usage of carnyx motives on the example no. 21, often encountered on fibulas and belt-parts during the second half of 2nd century.

Such fibulas are often found along the Rhine and the Danube Limes, much less in the inland. Numerous finds come Pannonia, Dacia and the Upper Moesia. In the Lower Moesia, they represent rare finds. Examples identical to the fibula no. 23 were previously already discovered at Viminaicum cemeteries (Redžić 2007: 48-49, T. XXIII/250-254), but also on some other sites in Serbia. It should be mentioned that an example was discovered at the Sarmathian site "Najeva ciglana" near Pančevo, which could indicate that the Sarmathians were the ethnic element using this fibula type. ${ }^{2}$

S. Rieckhoff-Pauli determined this fibula type into the already mentioned group $\mathrm{C}$, dated from the middle of $2^{\text {nd }}$ century (Rieckhoff-Pauli 1977: 21). A. Böhme also dates them from the middle of $2^{\text {nd }}$ to the beginning of $3^{\text {rd }}$ century (Böhme 1972: 44). After the Viminacium finds, the latest examples of plate-shaped fibulas made in the striking technique should be dated into the middle of $3^{\text {rd }}$ century.

A. K. Ambroz considers that two-ankled fibulas with an upturned foot (T. III/24) originate

2 During the visit to the Vršac museum, our colleague Miodrag Aralica showed me some unpublished fibulas of this variant coming from Sarmathian sites and I hereby wish to thank him for his kind help. 
from the territory of the southeastern Baltics and the lower Visla, brought by the Goths to the territory of the Chernyachow-Sintana-de-Mureş culture at the end of $2^{\text {nd }}$ and at the beginning of $3^{\text {rd }}$ century (Амброз 1966: 94). D. Bogdan and Cociş date them into 3 rd century, claiming that a great number of these fibulas was discovered at the territory of Dacia and considering that they were produced within this province and distributed in the neighbouring ones (Bogdan, Cociş 2006: 223-224). Gh. Diaconu considers such fibulas Roman provincial product (Diaconu 1971: 240). This fibula type is quite numerous at the territory of the Roman province of Upper Moesia, but also in the neighbouring provinces (Dacia, Lower Moesia). depending on the variant, they are dated from the second half of $3^{\text {rd }}$ to $6^{\text {th }}$ century. Similar examples found during previous excavations of the "Pećine" necropolis were dated into the second half of $3^{\text {rd }}$ century according to numismatic finds (Redžić 2007: 56, T.XXVI/291-292).

The here presented " $T$ "-shaped with a spring (T. III/25) was made of bronze and has a spring made of iron with a lower spring and a foot decorated with facceting. This type of fibulas developed from the earlier fibulas of Middle- and Late Iron Age schemes. The area from which such fibulas originate is the area of the Middle Danube valley and the territory of the Pzevorsk culture. Within the area of the Chernyachow-Sintana-deMureş, they are dated into $3^{\text {rd }}$ century. S. Petković dated them depending on the variant, generally from the second half of $3^{\text {rd }}$ to the first half of $5^{\text {th }}$ century (Petković 2010: 227-234). The previously discovered example of such a fibula was discovered at the site "Pećine", within the grave G-294. According to the find of a belt buckle and a ring from the same grave, it should be dated into the second half of $3^{\text {rd }}$ century. The fibula no. 25 should be dated into the second half of $3^{\text {rd }}$ century, since there are no older graves at this part of the "Pirivoj" cemetery.
In this collection there are 37 " $\mathrm{T}$ "-shaped fibulas with a hinge (including the here presented example T. III/26). At the end of $3^{\text {rd }}$ and at the beginning of $4^{\text {th }}$ century, cross-shaped fiblas developed from the " $T$ "-shaped ones (Jobst 1975: 88). The fibulas of this type are often found along the Limes, beginning with the German and the Raetian ones, over the Danubian, all the way down to Euphrates, indicating that they were worn by soldiers. In the Saalburg and Zugmantel fortresses, 126 examples of this type were found (Böhme 1972: 22-23). D. Popescu lists the finds of these finds in Dacia (Popescu 1945: 494-498, Abb. 6, 59-67, Abb. 7, 70-72). A great number of "T"shaped fibulas were found at Dura Europos, being connected to the transfer of military units during the reign of Septimius Severus (Jobst 1975: 87). Fibulas of this type are often encountered at the territory of the Upper Moesia.

Although D. Bojović dates this fibula type from the end of $2^{\text {nd }}$ to the beginning of $4^{\text {th }}$ century (Bojović 1983: 78), the author presumes that, according to the finds discovered so far at Viminacium, their dating should be reduced to $3^{\text {rd }}$ century.

The example no. 27 possesses a double fork-shaped bow ending with a cylindrical hull, in which there is an iron spring. This kind of fork-shaped fibulas with a spring in the hull was previously not discovered at Viminacium. The examples with a spring, either placed in a hull or being freely positioned, are typical for the Upper German and Raetian limes, are therefore considered as import from these provinices. Contrary to these, fork-shaped fibulas with a hinge are typical for Pannonia and the provincies to the east from it. This fibula type is dated at the end of $2^{\text {nd }}$ and into the first half of $3^{\text {rd }}$ century.

Cross-shaped fibulas represent the most numerous type at Viminacium, which is represented with 79 new finds, apart from the here presented examples (T. III/28-29). Typologically, both examples can be ascribed to the variant 3 of the cross-shaped fibulas from the Viminacium area 
(Redžić 2007: 68). P. M. Pretel included these fibulas into his type $3 / 4$, divided into four variants (A-D) according to the foot decoration. His variant $\mathrm{A}$ is dated into the second quarter of $4^{\text {th }}$ century and possesses geometrical ornaments on its foot (no. 28). Variant B, dated into the second half of $4^{\text {th }}$ century, possesses circular decoration on its foot (no. 29) (Pröttel 1988: 359-364). This variant is encountered at Viminacium and dated into the period from the fourth to the seventh decade of $4^{\text {th }}$ century. E. Keller determins these fibulas as types 3 (from 340 to 360 ) and 4 (from 350 to 380) (Keller 1971, 35, Abb. 12).

In this paper, 29 fibulas are presented for the first time, discovered during the latest Viminacium excavations. Included in the Viminacium fibula typology, it can be said that the here presented fibulas already appeared during the previous excavations. The only exception is the fork-shaped fibula with a string in a hull (no. 27), which is unique among the Viminacium fibula collection.

\section{CATALOGUE}

1. Bronze fibula with a fragmented needle. Finding place: "Kod bresta", 1997, C-1129. Length: $6.2 \mathrm{~cm}$

Dating: $2^{\text {nd }}$ and the first half of $3^{\text {rd }}$ century.

Unpublished.

2. Bronze fibula with a missing needle.

Finding place: "Na kamenju", 2007, C-102. Length: $7 \mathrm{~cm}$

Dating: $2^{\text {nd }}$ and the first half of $3^{\text {rd }}$ century. Unpublished.

3. Bronze fibula with a missing needle.

Finding place: "Kod bresta", 1997, C-1109.

Length: $5.5 \mathrm{~cm}$

Dating: $2^{\text {nd }}$ and the first half of $3^{\text {rd }}$ century. Unpublished.
4. Iron fibula with a missing needle

Finding place: "Više grobalja", 2009, C-12315.

Length: $4.9 \mathrm{~cm}$

Dating: $2^{\text {nd }}$ and the first half of $3^{\text {rd }}$ century.

Unpublished.

5. Iron fibula with a fragmented needle.

Finding place: "Pirivoj", 2006, C-958.

Length: $5.3 \mathrm{~cm}$

Dating: $2^{\text {nd }}$ and the first half of $3^{\text {rd }}$ century.

Unpublished.

Found in the skeletal grave G-339.

6. Bronze fibula, completely preserved.

Finding place: "Kod koraba", 2007, C-468.

Length: $4.5 \mathrm{~cm}$

Dating: $1^{\text {st }}$ and the first half of $2^{\text {nd }}$ century.

Unpublished.

7. Bronze fibula, preserved completely.

Finding place: "Na kamenju", 2007, C-36.

Length: $6.6 \mathrm{~cm}$

Dating: $1^{\text {st }}$ and the first half of $2^{\text {nd }}$ century.

Unpublished.

8. Bronze fibula, preserved completely.

Finding place: "Kod koraba”, 2006, C-342.

Length: $3.3 \mathrm{~cm}$

Dating: $2^{\text {nd }}$ and $3^{\text {rd }}$ century.

Unpublished.

Found in the cremation grave $\mathrm{G}_{1}-106$, along with the fibula 11 .

9. Bronze fibula, preserved completely. The lateral sides of the foot are decorated with carvings. Finding place: "Nad klepečkom”, 2008, C-20.

Length: $5.3 \mathrm{~cm}$

Dating: $2^{\text {nd }}$ and $3^{\text {rd }}$ century.

Unpublished.

10. Bronze fibula with a missing needle.

Finding place: "Terme", 2007, C-353.

Length: $3.5 \mathrm{~cm}$ 
Dating: End of $1^{\text {st }}$ to the middle of $3^{\text {rd }}$ century. Unpublished.

11. Bronze fibula with a missing needle and a part of the spring.

Finding place: "Kod koraba", 2006, C-337.

Length: $3.5 \mathrm{~cm}$

Dating: End of $1^{\text {st }}$ to the middle of $2^{\text {nd }}$ century. Unpublished.

Found in the cremation grave G-106, along with the fibula 6 .

12. Bronze fibula with a missing needle. The middle part of the foot is decorated with punctuated ornament.

Finding place: "Kod humke", 2004, C-13.

Length: $4.3 \mathrm{~cm}$

Dating: End of $1^{\text {st }}$ to the middle of $3^{\text {rd }}$ century.

Unpublished.

Found in the skeletal grave G-339.

13. Bronze fibula with a missing needle.

Finding place: "Kastrum”, 2002, C-23.

Length: $3.3 \mathrm{~cm}$

Dating: End of $1^{\text {st }}$ to the middle of $3^{\text {rd }}$ century. Unpublished.

14. Bronze fibula, preserved completely. The edge of the semi-circular supporting greda decorated with a carved zig-zag line.

Finding place: "Na kamenju", 2007, C-79.

Length: $3.7 \mathrm{~cm}$

Dating: $2^{\text {nd }}$ and the first half of $3^{\text {rd }}$ century. Unpublished.

15. Bronze fibula, preserved completely.

Finding place: "Kod koraba", 2005, C-208.

Length: $3.8 \mathrm{~cm}$

Dating: $2^{\text {nd }}$ and the first half of $3^{\text {rd }}$ century.

Unpublished.

Found in the cremation grave $\mathrm{G}_{1}-66$, along with a coin of Faustina the Elder.
16. Bronze fibula, completely preserved.

Finding place: "Rit", 2004, C-35.

Length: $3.6 \mathrm{~cm}$

Dating: $2^{\text {nd }}$ and the first half of $3^{\text {rd }}$ century.

Unpublished.

17. Bronze fibula, preserved completely.

Finding place: "Na kamenju", 2007, C-115.

Length: $3.7 \mathrm{~cm}$

Dating: Middle of $2^{\text {nd }}$ to the third quarter of $3^{\text {rd }}$ century.

Unpublished.

18. Brass fibula with a fragmented needle.

Finding place: "Više grobalja", 2009, C-12312.

Length: $3.4 \mathrm{~cm}$

Dating: the second half of $2^{\text {nd }}$ and the second third of $3^{\text {rd }}$ century.

Unpublished.

19. Bronze fibula with a missing needle. The plate-shaped body of the fibula is decorated with enamel in the millefiori technique. All four sides of the square body were decorated with changig white and black lines along the edges. In the corners there are black squares with white flowers in the middle. In the middle fibula part, there is a black square with white flowers in each corner.

Finding place: " Pećine", 2007, C-13558.

Length: $2 \mathrm{~cm}$

Dating: second half of $2^{\text {nd }}$ and the first half of $3^{\text {rd }}$ century.

Unpublished.

Found in the skeletal grave of a child G-5628.

20. Bronze fibula with a fragmented edge, decorated with carved concentric circles. The middle part is lifted and button-shaped, with a top decorated with blue enamel.

Finding place: "Više grobalja", 2009, C-12322.

Length: $3.6 \mathrm{~cm}$

Dating: the second half of $2^{\text {nd }}$ and the firts half of $3^{\text {rd }}$ century.

Unpublished. 
21. Silver fibula, completely preserved.

Finding place: "Stig", 2002, C-1.

Length: $4 \mathrm{~cm}$

Dating: the second half of $2^{\text {nd }}$ century.

Unpublished.

22. Silver fibula with a missing needle.

Finding place: "Kod koraba", 2005, C-33.

Length: $3.9 \mathrm{~cm}$

Dating: the second half of $2^{\text {nd }}$ century.

Unpublished.

It was found in a cremation grave $\mathrm{G}_{1}-13$, along with a worn-out coin minted during the reign of the Flavian dynsty, most likely being in a prolonged cirrculation.

23. Bronze fibula with a missing needle.

Finding place: "Kod bresta", 1997, C-1094.

Length: $3.3 \mathrm{~cm}$

Dating: the second half of $2^{\text {nd }}$ and the first half of $3^{\text {rd }}$ century.

Unpublished.

24. Iron fibula with a missing needle.

Finding place: "Pirivoj", 2007, C-1076.

Length: $7.3 \mathrm{~cm}$

Dating: the second half of $3^{\text {rd }}$ and $4^{\text {th }}$ century.

Unpublished.

25. Bronze fibula with a fragmented iron needle.

Finding place: "Pirivoj", 2006, C-828.

Length: $4.8 \mathrm{~cm}$

Dating: the second half of $3^{\text {rd }}$ century.

Unpublished.

It was found in a skeletal grave G-280. At this part of the cemetery, only graves from 2 nd and 3 rd century were discovered.

26. Bronze fibula with a missing needle.

Finding place: "Pirivoj", 2007, C-1042.

Length: $5.5 \mathrm{~cm}$

Dating: $3^{\text {rd }}$ century.

Unpublished.
27. Bronze fibula with a missing needle.

Finding place: "Pećine", 2007, C-13559.

Length: $6.3 \mathrm{~cm}$

Dating: the end of $2^{\text {nd }}$ and the beginning of $3^{\text {rd }}$ cen-

tury.

Unpublished.

28. Bronze fibula with a missing "onion-head".

Finding place: "Pirivoj", 1997, C-20.

Length: $8.1 \mathrm{~cm}$

Dating: second half of $4^{\text {th }}$ century.

Unpublished.

Found in the skeletal grave G-7.

29. Deformed bronze fibula, preserved completely.

Finding place: "Pirivoj", 2006, C-954.

Length: $6.3 \mathrm{~cm}$

Dating: second third of $4^{\text {th }}$ century.

Unpublished.

\section{BIBLIOGRAPHY}

Амброз А. К. 1966

Фибулы јога европейской части СССР ІІ в. до. 3. - $I V$ в.н.з., Москва: Российская Академия Наук, Институт Археологии.

Bichir, Gh. 1967

La civilisation des Carpes ( $\mathrm{II}^{\mathrm{e}}-\mathrm{III}^{\mathrm{e}}$ siècle de $\mathrm{n}$. è.) à la lumière des fouilles archéologiques de Poiana-Dulceşti, de Butnăreşti et de Pădureni, Dacia XI: 177-224.

\section{Bogdan, D., Cociş S. 2006}

Cociş, Roman brooches from Apulum, Apulum XLIII-1: 219-230.

Bojović, D. 1983

Rimske fibule Singidunuma, Beograd: Muzej grada Beograda. 


\section{Böhme, A. 1972}

Die Fibeln der Kastelle Saalburg und Zugmantel, Saalburg Jahrbuch XXIX, Saalburg: Werk - und Feindrucerai Dr Alexander Krebs.

\section{Cociş, S.2004}

Fibulele din Dacia romana (The Brooches from Roman Dacia), Cluj-Napoca: Mega 2004.

\section{Diaconu, Gh. 1971}

Über die Fibel mit umgeschlagenem Fuss in Dazien, Dacia XV.

\section{Ettlinger, E. 1973}

Die römischen Fibeln in der Schweiz, Bern: Francke verlag.

\section{Jobst, W. 1975}

Die Römischen fibeln aus Lauriacum, Linc: Druck - und verlagsanstalt m.b.h.

Jovanović, A. 1978

Nakit u rimskoj Dardaniji, Beograd: Savez arheooloških društava Jugoslavije.

\section{Keller, 1971}

Die spätrömischen Grabfunde in Südbayern, Münchner Beiträge zur Vor- und Frühgeschichte, Band 14, München: C. H. Becksche Verlagbhchhandlung.

\section{Koščević, R. 1975}

Die Werkstäte kräftig profierter fibeln in Siscia, Arheologia Iugoslavica, XVI, Beograd: Societas Archaeologia Iugoslaviae: 51-62.

\section{Korać, M., Golubović, S. 2009}

Viminacijum - Više Grobalja, Tom 2, Beograd: Arheološki institut.

\section{Petković, S. 2010}

Rimske fibule u Srbiji od I do V veka n.e., Beograd: Arheološki institut.

\section{Popescu, D. 1945}

Fibeln aus dem Nationalmuseum für Altertümer in Bukarest, Dacia IX-X: 485-505.

\section{Pröttel, P. 1988}

Zur Chronologie der Zweibelknopffibeln, Jahrbuch des Römischen-Germanischen Zentralmuseums Mainz, 35 Jahrgang, Teil 1: 347-372.

\section{Redžić, S. 2007}

Nalazi rimskih fibula na nekropolama Viminacijuma, Beograd: Centar za nove tehnologije, Arheološki institut.

\section{Rieckhoff, S. 1975}

Münzen und Fibeln aus dem Vicus des Kastells Hüfingen (Schwarcwald-Baar-Kreis), Saalburg Jahrbuch XXXII: 5-105.

\section{Rieckhoff-Pauli, S. 1977}

Die Fibeln aus dem römischen Vicus von Sulc am Necker, Saalburg Jahrbuch XXXIV: 5-29.

\section{Zotović, Lj., Jordović Č. 1990}

Nekropola „Više Grobalja“, Viminacium I, Beograd: Arheološki institut, Republički zavod za zaštitu spomenika. 


\section{REZIME}

\section{NEPUBLIKOVANI NALAZI}

RIMSKIH FIBULA SA

\section{TERITORIJE VIMINACIJUMA}

Ključne reči: fibule, Viminacijum, grobovi, naseobinske celine.

Predmet proučavanja ovog rada predstavljaju do sada nepublikovani nalazi rimskih fibula koje su nađene prilikom arheoloških istaživanja Viminacijuma novijeg datuma. Lokacije sa kojih potiču pomentuti nalazi su: Kod bresta, Pirivoj, Pećine, Više grobalja, Na kamenju, Humka, Kastrum, Terme, Kod koraba, Stig, Rit i Nad klepečkim. Prezentovane fibule su nalažene u grobovima, ali i unutar naseobinskih celina. Gledano iz ugla već postojeće tipologije fibula nađenih na prostoru Viminacijuma, skoro svi primerci su više ili manje frekfentno zastupljeni među pokretnim arheološkim nalazima nađenim tokom ranijih iskopavanja. Jedini izuzetak čini viljuškasta fibula sa oprugom u čauri (br. 27) koja u viminacijumskoj zbirci fibula predstavlja unikatni nalaz. 

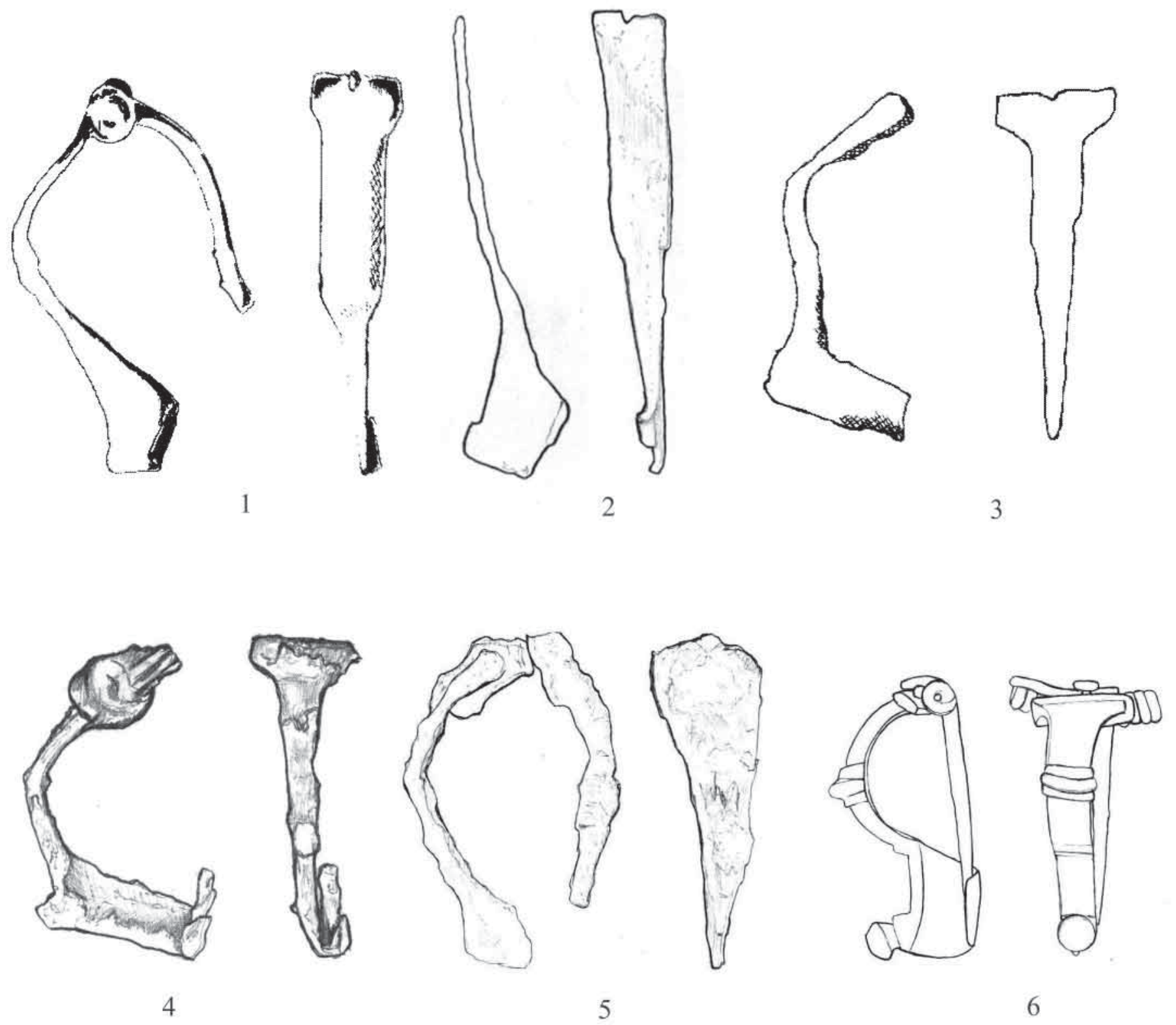

5

6
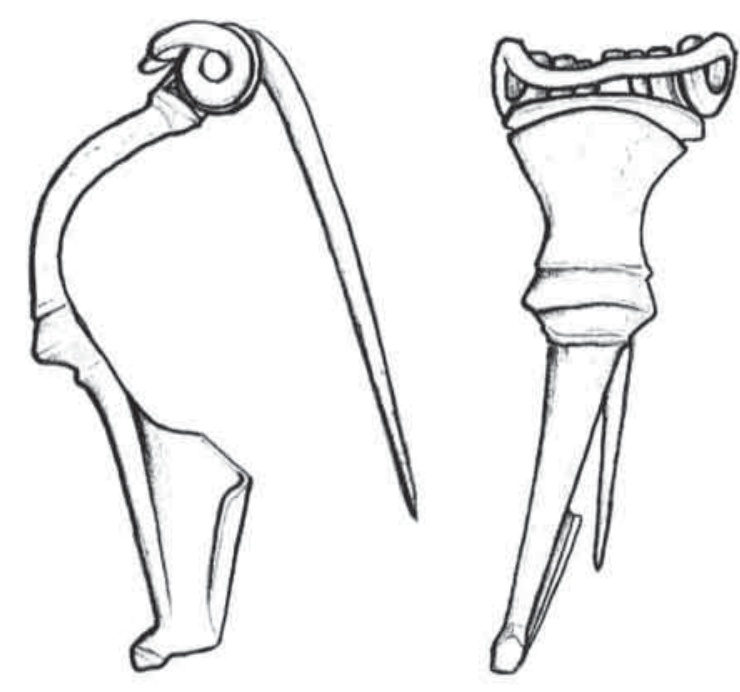

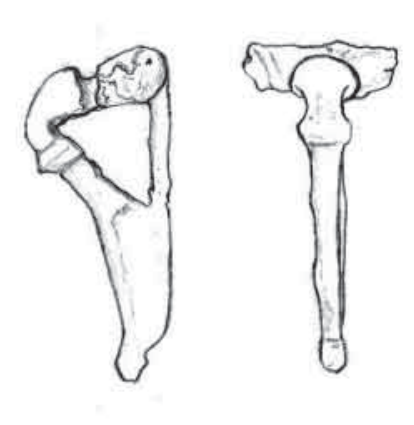

8

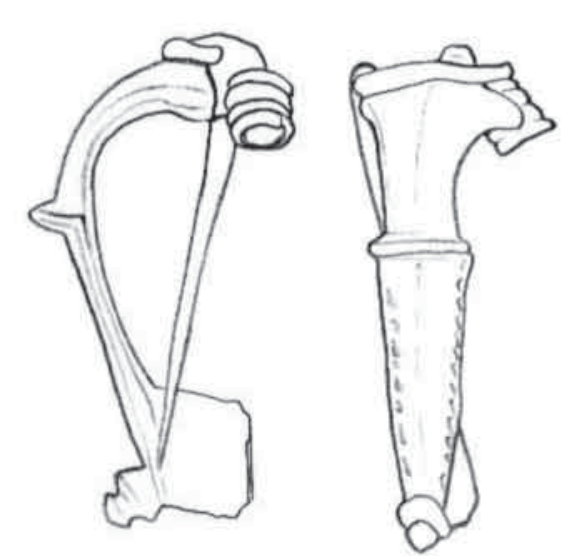

9

T.I/1-9, Razmera 1:1 


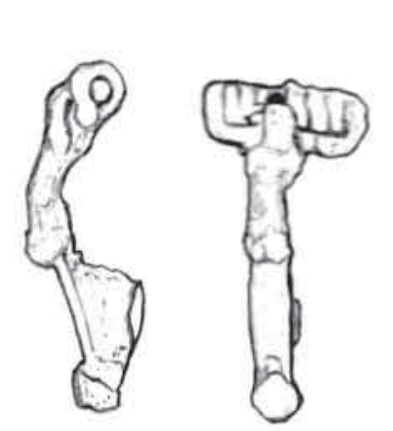

10

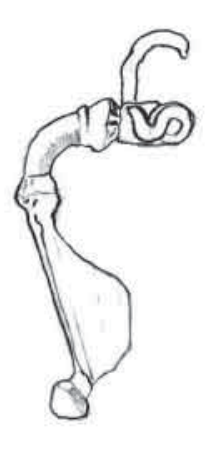

11

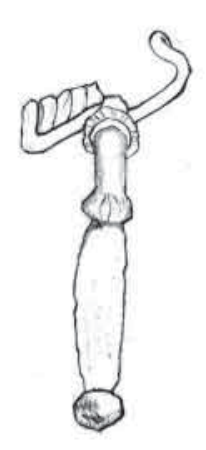

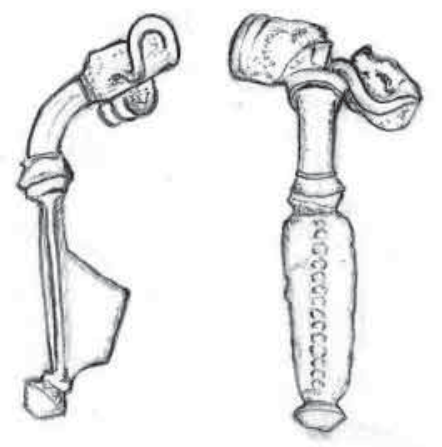

12

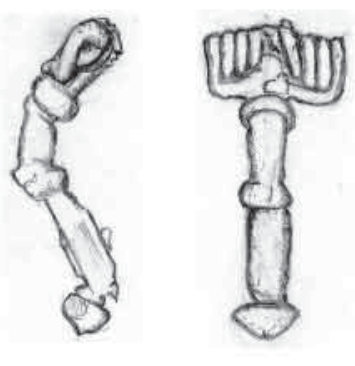

13

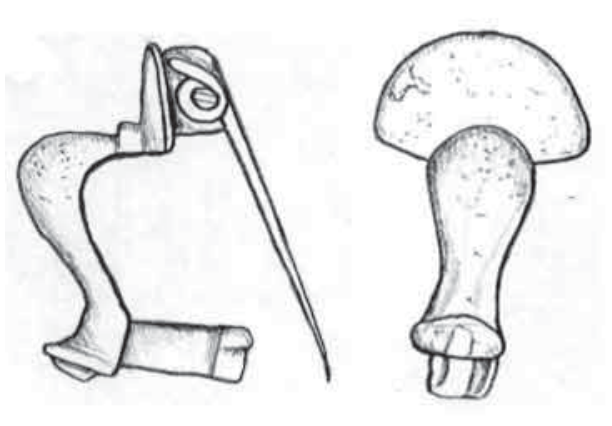

14

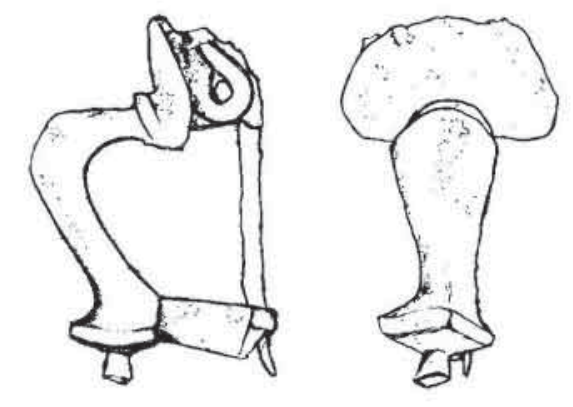

15

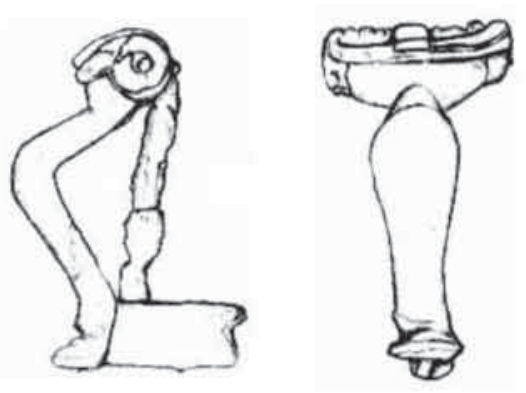

16

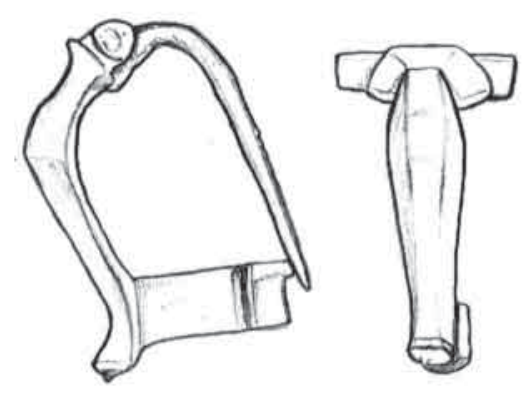

17

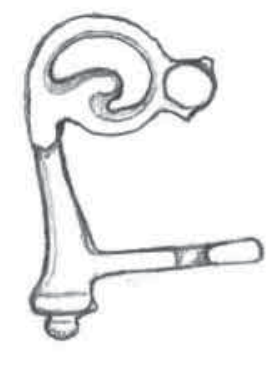

18

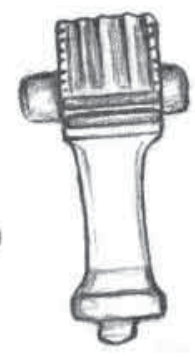

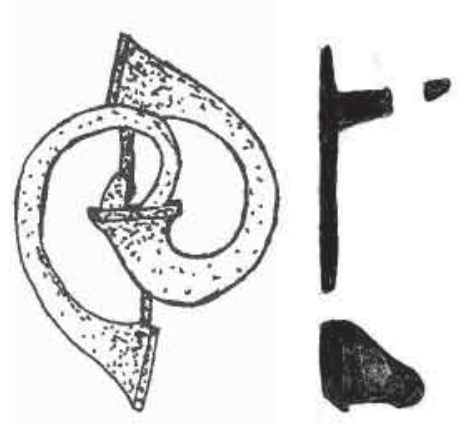

21

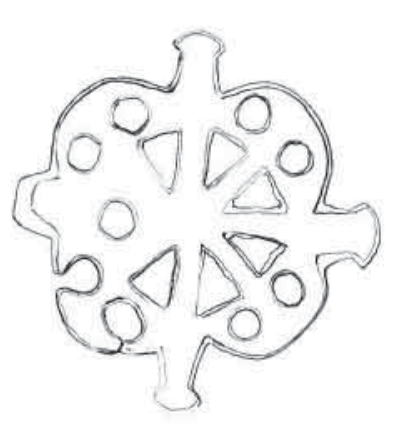

22
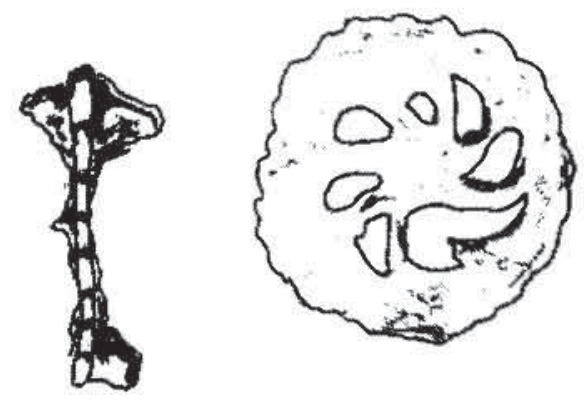

23

T.II/10-23, Razmera 1:1 

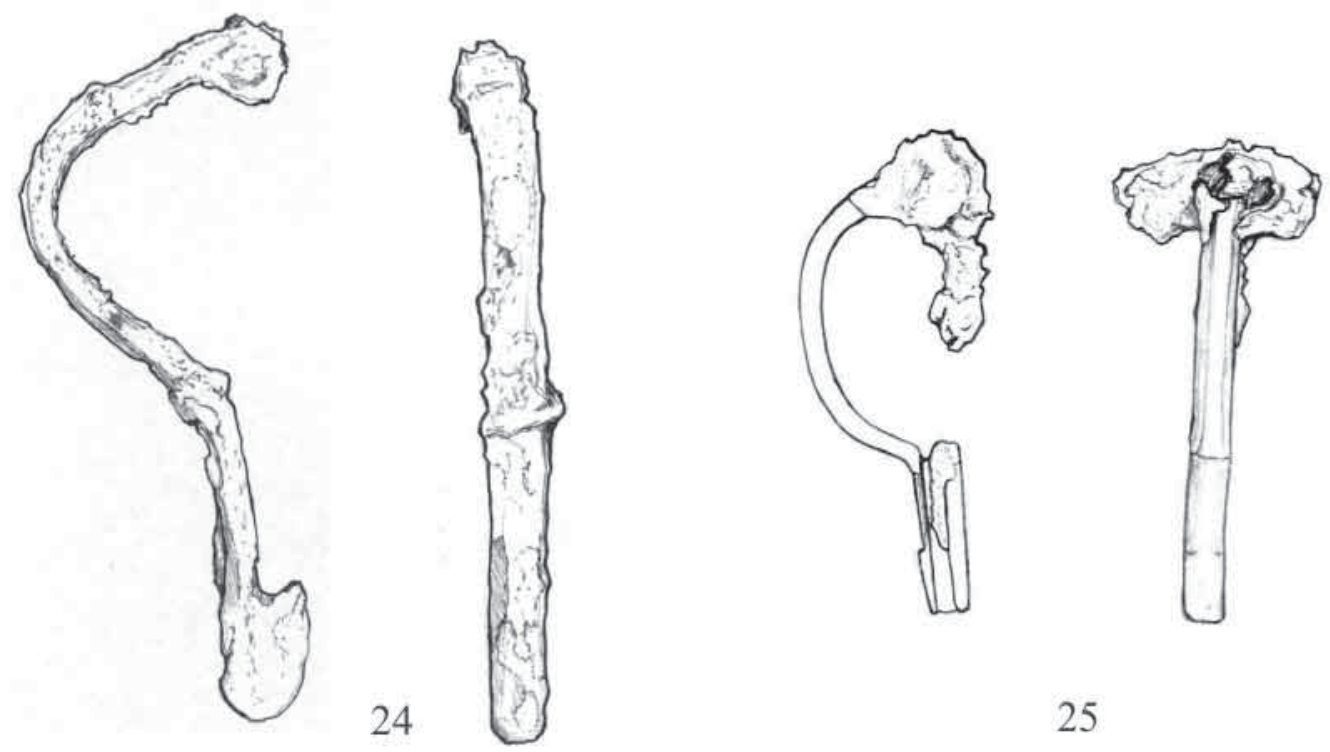

24
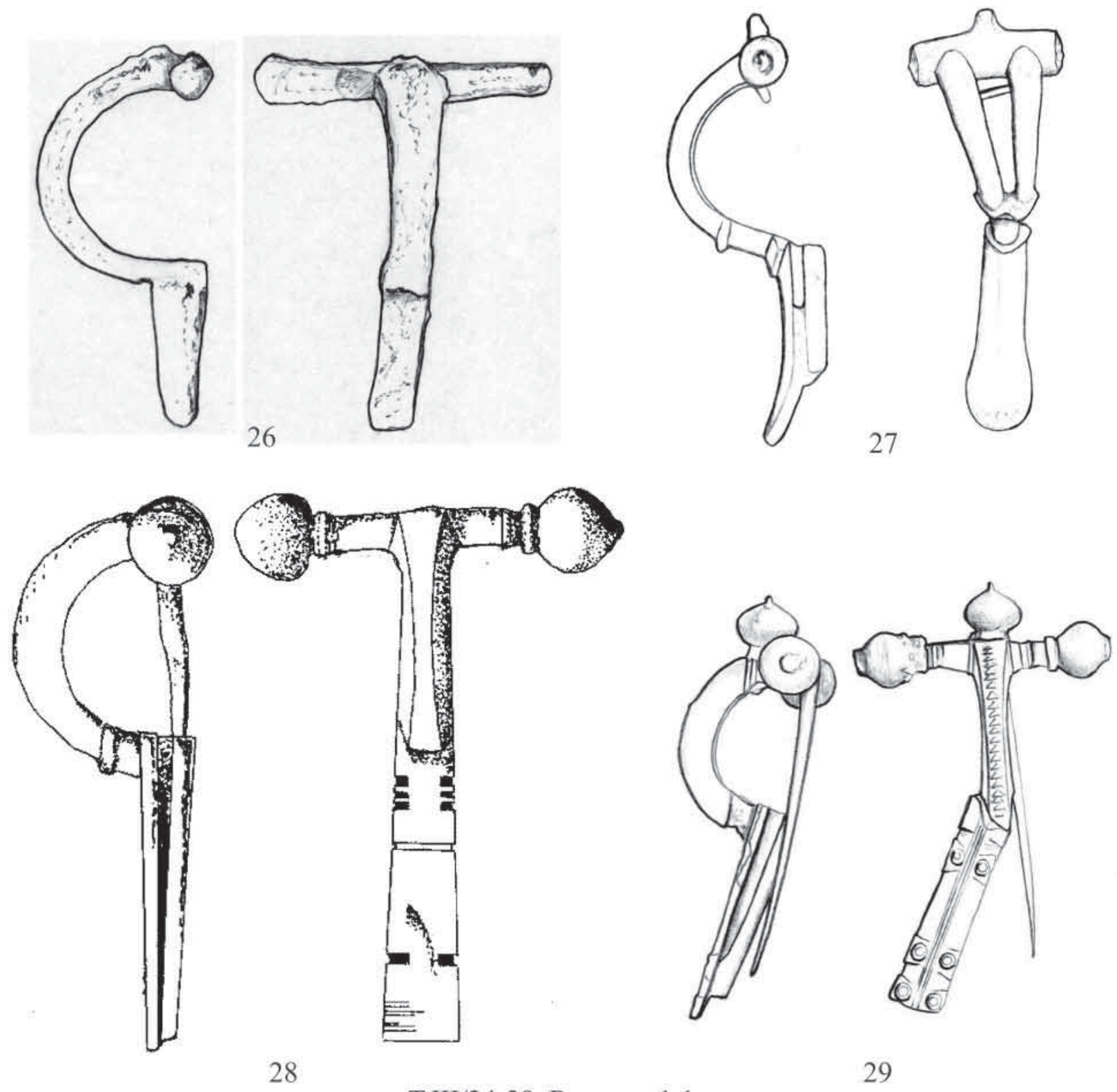

T.III/24-29, Razmera 1:1 